\title{
NOVÁKY Erzsébet
}

\section{0 éves a magyar jövőkutatás - Tanulmányok a jubileum alkalmából}

\section{Bevezető gondolatok}

Az Opus et Educatio immár másodszor közöl jövőkutatás témakörú tanulmányokat. 2016-ban (3. évfolyam, 4. szám) a Z generáció gondolatvilágának és jövőhöz való viszonyának témakörét állítottuk középpontba. Bemutattuk a Z generáció helyét a hazai generációk között, és a fiataljaink körében végzett empirikus vizsgálat eredményein keresztül e generáció tagjainak elképzeléseit, várakozásait az elkövetkező10 évre előre tekintve. Választ kerestünk arra, hogy mit tehetünk fiataljaink fizikai-lelki állapotának javítása érdekében, valamint arra, hogyan terjednek el az új infokommunikációs eszközök és közösségek a felsőoktatásban. Milyen jövőalternatívák várhatóak a technikai fejlődés oldaláról és milyen változások észlelhetők a hazai kulturális életben, a kulturáltsági színvonalban - ezek a témakörök is szerepeltek a Tanulmányok rovatban.

A 2019. év 2. számában a magyar jövőkutatás 50. évfordulója alkalmából rendezett tudományos konferencia előadásaiból, tanulmányaiból válogattunk. Az itt közölt tanulmányok az MTA IX. Osztály Statisztikai és Jövőkutatási Tudományos Bizottsága Jövőkutatási Tudományos Albizottságának szervezésében 2018. november 14-15. között lezajlott akadémiai konferencia (A múltból átívelő jövő VIII. Magyar (Jubileumi) Jövőkutatási Konferencia. 50 éves a magyar jövőkutatás) Fialatok a jövőért?! c. blokkja előadásainak kiegészített, tovább írt változatai.

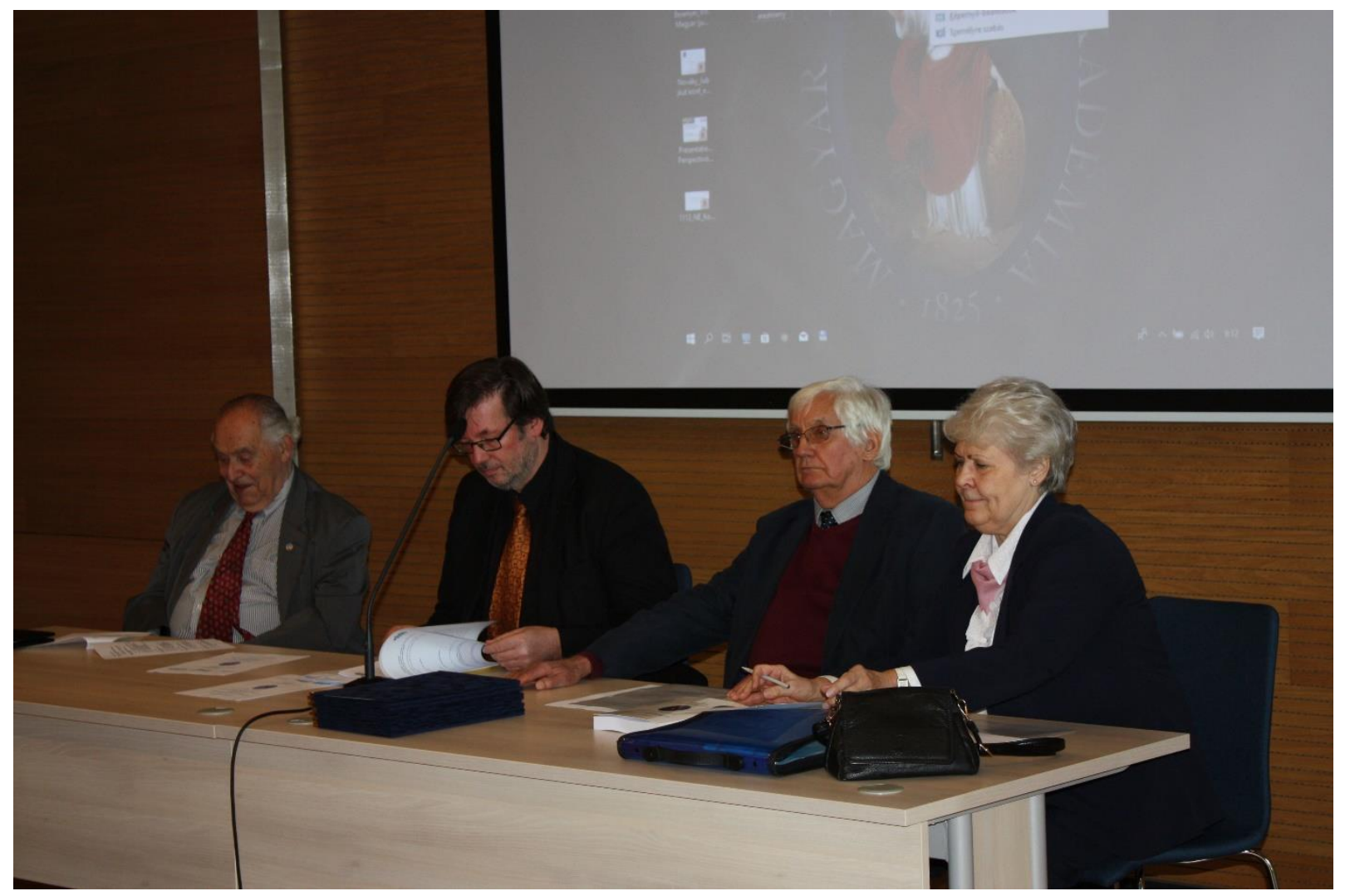

A magyar jövőkutatók nemcsak ezzel a konferenciával, hanem egy éves programsorozattal emlékeztek az intézményes magyar jövőkutatás megalapításának 50. évfordulójára. A programsorozat induló eseményeként néhai Kovács Gézára, az intézményes magyar jövőkutatás megalapítójának 90. 
születésnapjára emlékeztünk. Az év folyamán Egerben, Miskolcon, Sopronban és Pécsett kihelyezett tudományos üléseket szerveztünk, amelyeken a jövőkutatás egy-egy aktuális tudományos kérdéskörét vitattuk meg. A tudományos konferencia a programsorozat kiemelt eseménye volt.

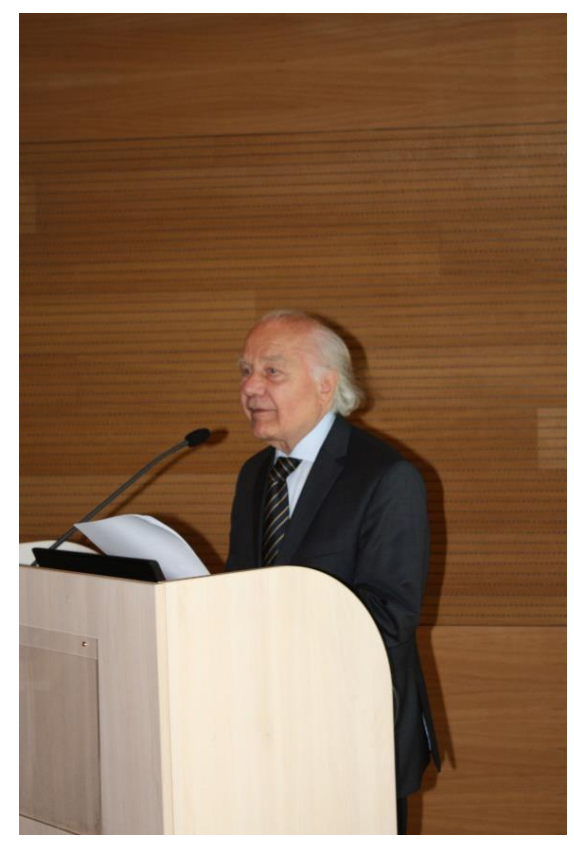

A multidiszciplinaritás jegyében megrendezett konferencia Vékás Lajos akadémikus, az MTA társadalomtudományi alelnökének köszöntőjével kezdődött. Beszédében megállapította: „A tudományos diszciplínák szolid aprómunkájának eredményei és ezeknek az eredményeknek interdiszciplináris összegzése segíti a jövőkutatást emberileg elérhető sikerhez. Büszkék lehetünk arra, hogy magyar kutatók, magyar tudományos intézetek már fél évszázad óta részt vállalnak ebben az igényes munkában."

A IX. Osztály nevében Palánkai Tibor üdvözölte a résztvevőket, hangsúlyozva az esemény fontosságát. A konferencia meghívott külföldi vendége Erik Øverland, a World Futures Studies Federation elnöke az Universal Perspectivism-ről fejtette ki gondolatait.

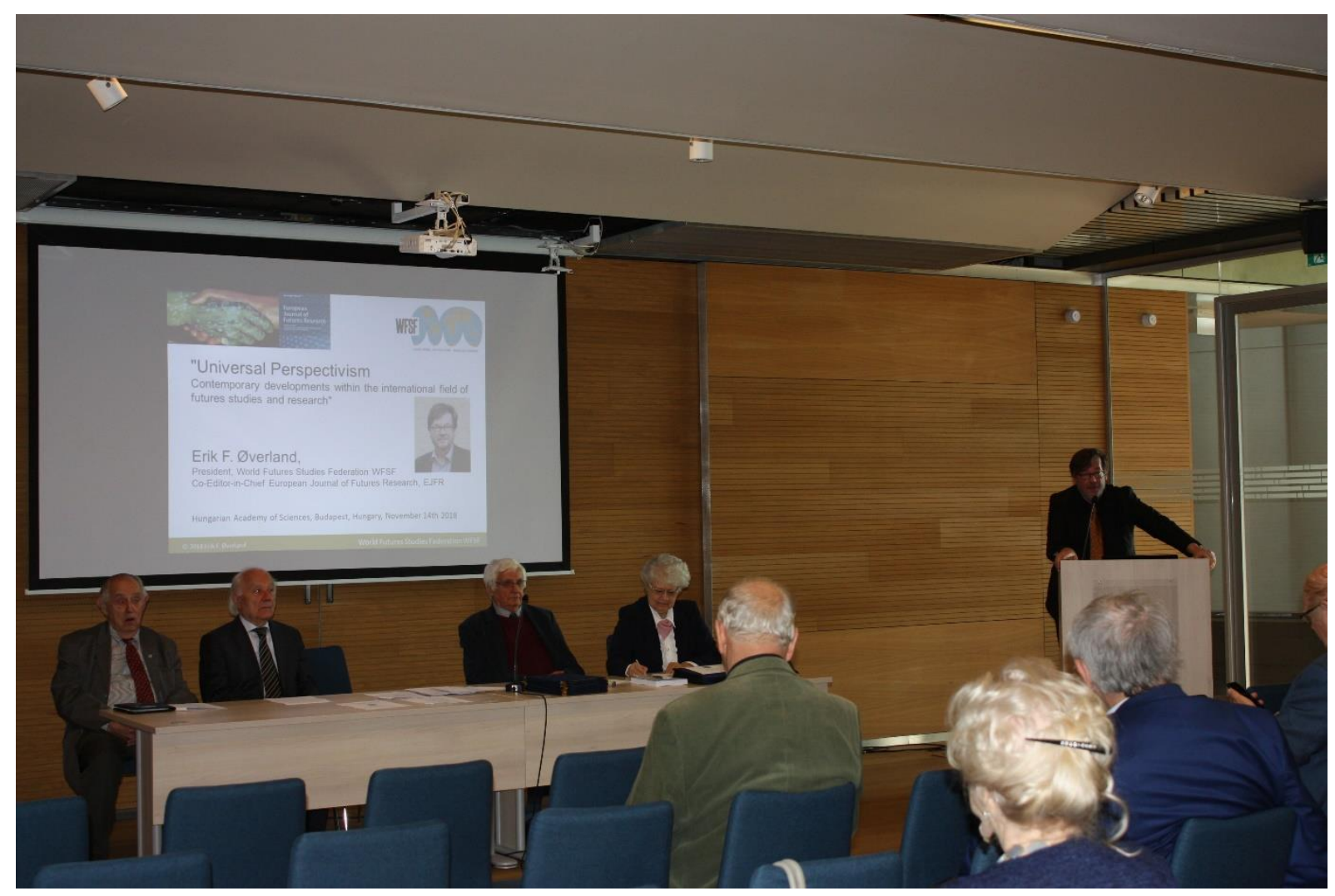


A jubileumi előadások a hazai jövőkutatás elmúlt 50 évének fejlődési ívét vázolták fel, kiemelve a nemzetközi jövőkutatáshoz való töretlen kapcsolódást. Simai Mihály felvázolta a felzárkózás lehetőségeit, Nováky Erzsébet a kutatási eredményekre és az akadémia szerepére összpontosított, Besenyei Lajos az üzleti prognosztika hazai és nemzetközi vetületére. A témablokkok vezetői - Nováky Erzsébet, Besenyei Lajos és Tóthné Szita Klára, Hideg Éva, Meskó Bertalan, valamint Tóth Attiláné gazdag programot állítottak össze. Öt témablokkban - kihívások a XXI. században, az üzleti prognosztika és kvantitatív módszertan, előrejelzés és foresight a kortárs jövőkutatásban, a jövő kulcsa: az emberi egészség és a fiatalok a jövőért - mutattuk be a jövőkutatás legújabb eredményeit. A tudományos előadások jövőkutatás-elméleti és módszertani kérdéseket érintettek, és a jövő olyan, kutatással alátámasztott problémaköreit boncolgatták, amelyek felvázolták a pozitív jövők létrejöttének esélyeit is. Kellő bölcsességgel kedvezőbb jövőbeni állapot is kiépíthető a globális és a geopolitikai változások fő irányai, a biztonság, különösen a környezeti biztonság, az egészségügyi kihívások és válaszok, valamint a jövőkutatási sztereotípiák területén. A szakmaspecifikus témák tágabb kontextusba helyezése igazolta a jövőkutatási megközelítésmód jelentőségét.

A 2019. évi (6. évfolyam) 2. számban Nováky Erzsébet tanulmánya átfogó képet ad a hazai jövőkutatás elmúlt 50 évéről, a fél évszázad alatt elért tudományos eredményekről és nemzetközi kapcsolatokról. Ezzel egyúttal keretet ad a fiatalok jövőelképzeléseit több oldalról bemutató további tanulmányoknak. A magyar jövőkutatás kezdetei 1968-ra nyúlnak vissza. A Római Klub alapításával egyidőben a Marx Károly Közgazdaságtudományi Egyetem Népgazdaság Tervezése Tanszékén Kovács Géza egyetemi tanár jövőkutatás témakörben kutató szemináriumot hirdetett, ami a jövőkutatás hazai egyetemi szintű oktatásának alapját képezte. A hazai jövőkutatás intézményes kereteinek kidolgozásával a cél a szocialista viszonyok közötti jövőkutatás sajátosságainak kutatása, elméleti-módszertani kérdéseinek tisztázása, a nemzetközi jövőkutatási szakirodalom gazdagítása, a kutatás és az oktatás szoros egységének fenntartása és a nemzetközi kapcsolatok kiépítése és bővítése volt. Az 50 év alatt elért eredmények igazolták ennek helyességét és létjogosultságát.

Hullám István és Tóth Attiláné tanulmánya egy, a felsőoktatásban tanulók körében 2008-ban és 2018ban végzett felmérés összehasonlító elemzés eredményeit közli. A szerzők azért látták indokoltnak a felmérés megismétlését, mert a 10 évvel ezelőtti válaszok több esetben eltértek előzetes várakozásaiktól. A szerzők 2018-ban is ugyanarra voltak kíváncsiak: a hallgatók milyen tudományok fejlődésétől várnak változásokat, mely tudománycsoportokat tekintenek fontosnak a jövő emberének élete szempontjából. A tanulmányból megtudható, hogy a fiatalok milyennek képzelik el a jövő embereit, milyen jellemző tulajdonságaik lesznek a társadalom tagjaira, milyen lesz az életük 20 év múlva.

Gáspár Tamás tanulmánya a munka világába kalauzol bennünket, ahogyan az általános iskolások jövőképében az megjelenik. A kutatás indokoltságát az adta, hogy az új ipari forradalom (Ipar 4.0) néhány évtizeden belül alapvetően megváltoztatja a munka világát. Ebben az időtávban ugyanakkor egy generációváltás is lezajlik. A jövőbeni munkaerőpiac meghatározó részét azok adják, akik ma kisiskolás korúak. Ez az életkor nagyon érzékeny, a képességek, normák alakításának, a nevelésnek alapvető időszaka. Ezért fontos kérdés, hogy mi van a gyerekek fejében a munka világáról. A tanulmány egy esettanulmány egy átlagos általános iskolai osztály 8-9, illetve 14-15 éves tanulóiról.

Koncz Gábor írása bemutatta és elemezte azokat a rajzokat, amelyek a Tudományos Ismeretterjesztő Társulat Stúdió Egyesület (TIT SE) által 2018-ban meghirdetett és megszervezett az „Egy napom a jövőben" gyermek-rajz verseny és kiállítás keretében készültek. A versenyen Budapest XI. kerület alsó tagozatos iskolásai vettek részt. Az alkotások 44 rajz és egy vers formát öltöttek. A fotóval illusztrált írás a verseny és kiállítás előzményeit, jellemzőit tekinti át, szülői egyetértéssel.

Tóthné Szita Klára, Gál Jolán és Kristóf Tamás tanulmánya egy új empirikus vizsgálat keretében feltárta a hazai fiatalok jövővel kapcsolatos gondolatait, várakozásait, reményeit és félelmeit, 20 és 50 éves előre tekintéssel. Az alkalmazott módszerek között szerepelt az irányított brainstorming, a papír alapú kérdőíves felmérés és a közösségi média felhasználásával online kérdőív alkalmazása. Összességében 
1204 fiatal vett részt a kutatásban, és adott értékelhető válaszokat a felmérésben szereplő kérdésekre. Az empirikus felmérés keretében vizsgált kérdések a világ, Magyarország, a környezeti állapot, az energetika, az oktatás, a tudomány és a technológia, az egészség, a család és a személyiség, a munka világának és a közlekedés jövőjére, valamint a személyes élettel kapcsolatos várakozásokra terjedtek ki. Az eredmények alapján megállapítható, hogy a fiatalok jövővel kapcsolatos várakozásai, a változásokat illetően nagyobbrészt kedvezőnek mondhatók.

A retrospektív és az előre tekintő tanulmányokat fotók, rajzok színesítik, kihasználva az on line megjelenés lehetőségeit. Megnyugtató volt azt látni és hallani, hogy fiataljaink a jövőnek nemcsak a katasztrófajellegú, hanem a kedvező változatát is el tudják képzelni, és ha szükséges, tennének is érte.

Kedves Olvasó! Ismerkedjen meg az itt leírtakkal és gondolkodjon el azon, hogy Ön mit tenne - és mit tesz - azért, hogy Magyarország jövője jó irányban változzon és a következő generációk kedvezőbb életkilátások közepette éljenek boldog, családi életet. 